\title{
KETERDEDAHAN TERHADAP TAYANGAN IKLAN DAN SIKAP IBU DALAM MEMBERI PANGAN BALITA (DESA PADASUKA, KECAMATAN CIOMAS, KABUPATEN BOGOR)
}

\section{Ads Exposured Againts Ad Impressions Mother's Attitude in Giving Food for a Toddler (Case of Padasuka Village, Ciomas Sub-district, Bogor District)}

\author{
Annisa Idzni Yusrina ${ }^{1)}$ dan Nuraini W Prasodjo ${ }^{1)}$ \\ ${ }^{1)}$ Departemen Sains Komunikasi dan Pengembangan Masyarakat, Fakultas Ekologi Manusia, \\ Institut Pertanian Bogor, Darmaga Bogor 16680, Indonesia \\ E-mail: aidzniyusrina@gmail.com; eniprasodjo@apps.ipb.ac.id
}

\begin{abstract}
Infancy is the period a very important life and need special attention from the parents. Most parents are instrumental in growing flower child is the mother. Attitude is thought to be the function of the knowledge gained through the media ad impressions. This research the correlation of knowledge and the ads exposure food and knowledge about advertising with the attitude of the mother in the giving of food on a toddler. Type of this research in quantitative research with survey method of qualitative data supported by in-depth in interview method. Respondents consist of 40 of mother. The results showed a significant correlation ads exposured levels against the level of knowledge of the mother and the level of knowledge of the food the mother has in giving food on toddlers.
\end{abstract}

Keywords: ads exposured, attitude, knowledge

\begin{abstract}
ABSTRAK
Masa balita merupakan masa kehidupan yang sangat penting dan perlu perhatian yang khusus dari orangtua. Orangtua yang paling berperan dalam tumbuh kembang anak adalah ibu. Sikap diduga merupakan fungsi dari pengetahuan yang diperoleh melalui media tayangan iklan. Penelitian ini bertujuan untuk mengetahui hubungan keterdedahan iklan tentang pangan dan pengetahuan dengan sikap ibu dalam memberi pangan pada balita. Jenis penelitian ini adalah penelitian kuantitatif dengan metode survei yang didukung data kualitatif dengan metode wawancara mendalam. Responden terdiri dari 40 orang ibu. Hasil penelitian menunjukkan tingkat keterdedahan memiliki hubungan signifikan dengan tingkat pengetahuan ibu dan tingkat pengetahuan pangan ibu tidak memiliki hubungan signifikan dengan sikap ibu dalam memberi pangan pada balita.
\end{abstract}

Kata kunci: keterdedahan iklan, pengetahuan, sikap

\section{PENDAHULUAN}

Masa balita merupakan masa pertumbuhan dan perkembangan berat badan yang paling pesat dibanding dengan kelompok umur lain, masa ini tidak terulang sehingga disebut window of opportunity, untuk mengetahui apakah balita tumbuh dan berkembang secara normal atau tidak, penilaian tumbuh kembang balita yang mudah diamati adalah pola tumbuh kembang fisik, salah satunya dalam mengukur berat badan balita (Soetjiningsih 2002).

Badan kesehatan dunia (WHO 2011) memperkirakan bahwa 54\% kematian anak disebabkan oleh keadaan gizi yang buruk. Di Indonesia, saat ini tercatat $4.5 \%$ dari 22 juta balita atau 900 ribu balita di Indonesia mengalami gizi 
kurang atau gizi buruk dan mengakibatkan lebih dari 80\% kematian anak (Kemenkes 2012).

Perkembangan teknologi informasi dan komunikasi pada era modernisasi sekarang ini terus meningkat. Media massa khususnya televisi sudah semakin berkembang, teknologi semakin canggih dan semakin tersebar luas ke seluruh pelosok Indonesia hingga ke pedesaan. Dapat dikatakan televisi sekarang ini menjadi budaya massa. Televisi pada hakikatnya memiliki fungsi sebagai media hiburan, pendidikan, dan informasi. Tetapi realitanya sekarang ini tayangan-tayangan televisi (swasta) lebih banyak mengarah kepada aspek hiburan dan informasi (Ardianto 2001). Orientasi stasiun-stasiun televisi lebih mengarah kepada orientasi keuntungan dan komersial terlihat dari sebagian besar tayangan iklan yang disiarkan televisi adalah iklan komersial, yaitu iklan yang bertujuan untuk meraih konsumen demi mendapatkan keuntungan. Orientasi keuntungan dari stasiun televisi tersebut menyebabkan tayangan iklan komersial sekarang ini terus meningkat, ditambah lagi dengan keinginan untuk mengejar rating setinggi mungkin.

Secara umum, tujuan iklan adalah untuk mencapai perubahan pada diri masyarakat, sehingga mengaplikasikan pesan persuasi yang disampaikan melalui iklan ke dalam kehidupannya. Hal ini dapat mengarah kepada perubahan sikap yang dalam penelitian ini akan dianalisis dengan menggunakan komponen kognisi, afeksi dan konasi (Schiffman dan Kanuk 1994). Iklan melalui televisi memang mempunyai efek yang luar biasa dibandingkan dengan melalui media lainnya. Bukan hanya dari pendidikan saja seorang ibu dapat menambah pengetahuan. Iklan menjadi salah satu sumber informasi yang dapat menambah pengetahuan seseorang yang melihatnya sehingga dapat meningkatkan pengetahuan dan menambah informasi yang dibutuhkan oleh seseorang, terutama seorang ibu.

Iklan pangan harus menampilkan keterangan yang benar, serta tidak memberikan keterangan yang menyesatkan. Keterangan yang benar adalah memberikan informasi yang sesuai dengan kenyataan sebenarnya atau memuat semua keterangan yang diperlukan agar keterangan tersebut dapat memberikan gambaran atau kesan yang sebenarnya tentang pangan. Contoh iklan yang dapat menambah informasi dan meningkatkan pengetahuan ibu adalah iklan bubur bayi instan : milna, promina, nestle cerelac, susu formula : dancow, morinaga, bebelac, sgm. Iklan tersebut memberikan informasi sekaligus memberikan pesan bahwa iklan biskuit dan bubur yang ditayangkan makanan pendamping air susu ibu (ASI) yang melengkapi kebutuhan energi dan memberikan nutrisi seimbang. Makanan bertekstur lembut sesuai perkembangan indera pengecap dan perkembangan fungsi pencernaannya. Dengan isi pesan yang menjelaskan seperti itu, maka akan perubahan sikap ibu dalam pemberian makanan pada balita. Terdapat empat permasalahan penelitian yaitu: 1) Bagaimana hubungan keterdedahan tayangan iklan televisi dengan pengetahuan pangan ibu?, 2) Bagaimana hubungan motif menonton tayangan iklan televisi dengan pengetahuan pangan ibu?, 3) Bagaimana hubungan pangan ibu dengan sikap ibu memberi pangan balita?

\section{PENDEKATAN TEORITIS}

\section{Keterdedahan Tayangan Iklan}

Menurut Rodman (2006) keterdedahan adalah proses seseorang untuk mencari pesan yang dapat membantu mereka dalam menentukan sikap atau perilaku. Keterdedahan khlayak terhadap siaran televisi diartikan bagaimana khalayak mengkonsumsi berbagai program acara yang disuguhkan televisi untuk memenuhi kebutuhan khalayak. Televisi sebagai salah satu media massa dianggap mampu memenuhi kebutuhan khalayak baik kebutuhan akan informasi maupun hiburan.

Menurut Andika (2008) menyatakan bahwa salah satu cara untuk mengetahui keterdedahan seseorang terhadap media massa adalah dengan melihat intesitas mereka dalam menggunakan media massa. Media massa yang akan diamati adalah media massa yang memiliki porsi paling besar dalam kehidupan. Dengan demikian, sejalan pula dengan kelebihan televisi yaitu sebagai a prime source a prime source of news, maka dalam penelitian ini keterdedahan didefinisikan sebagai intensitas seseorang dalam melihat iklan yang ditayangan di televisi. 
Berdasarkan pendapat di atas, dapat disimpulkan pengertian keterdedahan tayangan iklan adalah intensitas seseorang untuk mencari dan menangkap pesan lewat tayangan iklan yang dapat membantu dalam menentukan sikap. Keterdedahan terhadap iklan televisi dapat diukur melalui beberapa indikator, seperti: jenis iklan yang selalu tayang, menonton selingan iklan, menyukai dan tidak menyukai jenis iklan, cara menonton, tempat menonton, alasan menonton, kemudahan memahami atau menangkap pesan iklan, kesesuaian dengan kebutuhan, ketertarikan pada iklan. Namun. Hal ini di dukung oleh pendapat Sutisna (2000) bahwa faktor yang mempengaruhi keterdedahan terhadap iklan salah satunya adalah motivasi menonton. Motivasi menonton televisi dapat dikategorikan dalam mencari informasi, hiburan, menambah pengetahuan, mengisi waktu luang, dan menemani keluarga. Hasil penelitian yang dilakukan Sutisna (2000) menunjukkan bahwa motivasi masyarakat untuk menonton televisi adalah motivasi hiburan dan informasi. Dampak tayangan iklan televisi bisa memunculkan dampak positif atau negatif.

\section{Pengetahuan Pangan Ibu}

Menurut Notoatmodjo (2007), pengetahuan merupakan domain yang sangat penting dalam membentuk tindakan seseorang. Pengetahuan adalah hasil "tahu" yang terjadi setelah penginderaan terhadap suatu objek tertentu.

Menurut Wijaya (1996) menyatakan bahwa pengetahuan yang baik dipengaruhi oleh informasi yang diterima dan faktor pengalaman. Faktor pengalaman merupakan salah satu cara pokok manusia untuk mendapatkan pengetahuan. Penyerapan pengetahuan melalui pengalaman ini berdasarkan pada pengamatan terhadap gejalagejala yang timbul melalui tanggapan panca indera manusia. Seseorang yang telah lama hidup tentunya telah mengalami banyak hal dan memperoleh berbagai informasi yang akan menambah pengetahuannya. Hal ini sesuai sekali dengan ungkapan sebuah pepatah yang mengatakan bahwa orang yang lebih tua telah banyak makan asam garam.

Melalui pengetahuan yang dikembangkan manusia dapat hidup, dapat merubah sikap dan tingkah lakunya, dapat mengetahui sesuatu itu tidak benar, baik atau tidak baik, indah atau tidak indah. Manusia mengembangkan pengetahuan dengan kemampuan penaralannya agar dapat mengatasi kebutuhan dan keinginan hidup demi kelangsungan hidupnya. Pengetahuan merupakan fungsi dari sikap. Menurut fungsi ini manusia mempunyai dorongan dasar untuk ingin tahu, untuk mencari penalaran dan untuk mengorganisasikan pengalamannya. Pengetahuan serta kesukaan ibu terhadap jenisjenis makanan tertentu sangat berpengaruh hidangan-hidangan yang disajikan oleh ibu setiap hari bagi keluarga khususnya untuk balita (Suhardjo 1989).

Pengertian pangan menurut Peraturan Pemerintah RI nomor 28 tahun 2004 adalah segala sesuatu yang berasal dari sumber hayati dan air, baik yang diolah maupun yang tidak diolah, yang diperuntukkan sebagai makanan atau minuman bagi konsumsi manusia, termasuk bahan tambahan pangan, bahan baku pangan, dan bahan lain yang digunakan dalam proses penyiapan, pengolahan, dan atau pembuatan makanan atau minuman. Jadi pengetahuan ibu tentang pangan balita dapat diartikan sebagai segala apa yang diketahui oleh ibu tentang sumber hayati yang diolah maupun yang tidak diolah yang diperlukan sebagai makanan atau minuman bagi pertumbuhan dan kesehatan badan balita.

Beberapa faktor yang menyebabkan banyaknya masalah yang timbul mengenai gizi buruk pada balita adalah faktor ekonomi, lingkungan, dan ketidaktahuan orangtua. Faktor yang paling terlihat di lingkungan masyarakat adalah kurangnya pengetahuan ibu mengenai gizi yang harus dipenuhi anak pada masa pertumbuhan. Salah satu usaha untuk menanggulangi kekurangan gizi pada bayi dan balita dibutuhkan suatu pengetahuan dari keluarga. Pengetahuan tersebut dapat diperoleh dari informasi-informasi yang ada di media masa, selebaran maupun dari petugas kesehatan. Dalam teori perilaku Notoatmodjo yang menyatakan, dari pengetahuan dan sikap yang baik akan terwujud tindakan yang baik pula (Notoatmodjo 2003). 


\section{Sikap Ibu Memberi Pangan Balita}

Sikap mencerminkan suka tidaknya seseorang terhadap kategori benda, orang atau situasi tertentu. Kerapkali sikap berasal dari pengalaman kita sendiri atau pengalaman orang lain yang dekat dengan kita. Sikap dapat membuat kita tertarik pada sejumlah hal atau membuat kita menjauhi hal tersebut. Kadang-kadang sikap terbentuk berdasarkan pengalaman yang terbatas. Oleh karena itu, masyarakat dapat membentuk sikapnya tanpa memahami keseluruhan situasi. Masyarakat mungkin tidak ingin mengubah cara pengolahan makanan yang tradisional kendati cara tersebut terbukti tidak aman. Beberapa penjamah makanan mungkin tidak senang jika diajarkan cara bagaimana mengolah makanan secara higienis (Hartono 2006).

Sikap gizi merupakan perasaan, keyakinan, dan kecenderungan untuk bertindak dalam pengolahan pangan jajanan yang memperhatikan kandungan gizi, serta keamanan pangan agar menghasilkan pangan jajanan yang aman. Sikap seseorang sangat menentukan bagaimana tindakan orang tersebut. Jika sikap seseorang terhadap suatu hal dapat diketahui, maka dapat diduga bentuk tindakan apa yang akan dilakukan oleh orang itu. Tidak tertutup kemungkinan bahwa tindakan yang dilaksanakan tidak sejalan dengan sikap yang telah diambilnya (Taryoto 1991).

Sikap dapat bersifat positif dan negatif, pada sikap positif terdapat kecenderungan tindakan mendekati, menyenangi, dan mengharapkan pada objek tertentu sedangkan pada sikap negatif terdapat kecenderungan tindakan menjauhi, menghindari, membenci, tidak menyukai pada objek tertentu (Sarwono 2002).

Menurut (Azwar 2003), teori yang mengungkapkan latar belakang atau alasan suatu tindakan dapat dilihat melalui Theory of Planned Behavior oleh Ajzen dan Fishbein. Sikap ini ditentukan oleh dua hal yaitu, kepercayaan atau keyakinan (belief) tentang konsekuensikonsekuensi dari perilaku, dan evaluasi terhadap konsekuensi tersebut untuk diri subjek itu sendiri. Tekanan sosial yang dirasakan (norma subjektif) untuk melakukan perilaku. Norma subjektif ditentukan oleh dua hal, yaitu pendapat tokoh atau orang lain yang dianggap penting (significant others) serta seberapa jauh subjek akan mengikuti pendapat orang lain tersebut. Sikap terhadap perilaku bersama norma subjektif membentuk niat untuk berperilaku. Dalam menentukan perilaku yang akan muncul kepada seseorang maka dapat dilihat bahwa akan ada hal lain yang juga akan ikut terlibat dalam pembentukan perilaku tersebut selain sikap.

\section{Kerangka Pemikiran}

Ibu memiliki banyak peran di dalam menjalankan kesehariannya. Peranan ibu sebagai istri dan ibu dari anak- anaknya, mengurus rumah tangga, sebagai pengasuh dan pendidik anak-anaknya, dan sebagai salah satu kelompok dari peranan sosialnya serta sebagai anggota masyarakat dari lingkungannya merupakan hal yang perlu dilakukan secara bersamaan sehinggga seorang ibu memerlukan pengetahuan yang luas agar dapat memainkan perannya secara baik dan maksimal. Pengetahuan ibu tidak hanya dari pendidikan formal melainkan dari pendidikan non-formal juga bisa ibu dapatkan.

Menurut Rodman (2006) dikutip oleh Andika (2008) juga mendefinisikan keterdedahan sebagai proses seseorang untuk mencari pesan yang dapat membantu mereka dalam menentukan sikap atau perilaku. Keterdedahan khalayak terhadap siaran televisi diartikan bagaimana khalayak mengkonsumsi berbagai program acara yang disuguhkan televisi untuk memenuhi kebutuhan khalayak. Televisi sebagai salah satu media massa dianggap mampu memenuhi kebutuhan khalayak baik kebutuhan akan informasi maupun hiburan. Namun, pada akhirnya khalayak akan memilih berbagai jenis tayangan televisi yang dapat memuaskan kebutuhan pribadinya salah satunya seperti tayangan berita.

Pengetahuan tidak memiliki keterbatasan. Pengetahuan dapat didapatkan oleh seseorang dimanapun dan kapanpun. Berdasarkan penelitian Notoatmodjo (2007) dan Poerwodarminto (1976) pengetahuan akan mempengaruhi tindakan seseorang. Pengetahuan merupakan domain yang sangat penting dalam membentuk tindakan seseorang. Pengetahuan adalah hasil "tahu" yang terjadi setelah penginderaan terhadap suatu objek tertentu. 
Namun menurut penelitian hasil penelitian Rakhmawati (2014) yaitu terdapat hubungan yang signifikan antara sikap memberi makan anak dengan status gizi anak, tetapi masih perlu adanya informasi mengenai modifikasi makanan yang disenangi anak.

Tingkat pengetahuan ibu dapat berubah seiring waktu sesuai dengan kebutuhan ibu untuk mencari informasi dan belajar hal-hal baru. Salah satunya, pengetahuan dapat diperoleh seorang ibu melalui iklan di televisi. Bukan hanya dari pendidikan saja seorang ibu dapat menambah pengetahuan. Iklan menjadi salah satu sumber informasi yang dapat menambah pengetahuan seseorang yang melihatnya sehingga dapat meningkatkan pengetahuan dan menambah informasi yang dibutuhkan oleh seseorang, terutama seorang ibu. Hubungan antara keterdedahan dan pengetahuan dengan sikap yang dibangun dijelaskan dalam kerangka berpikir pada Gambar 1.

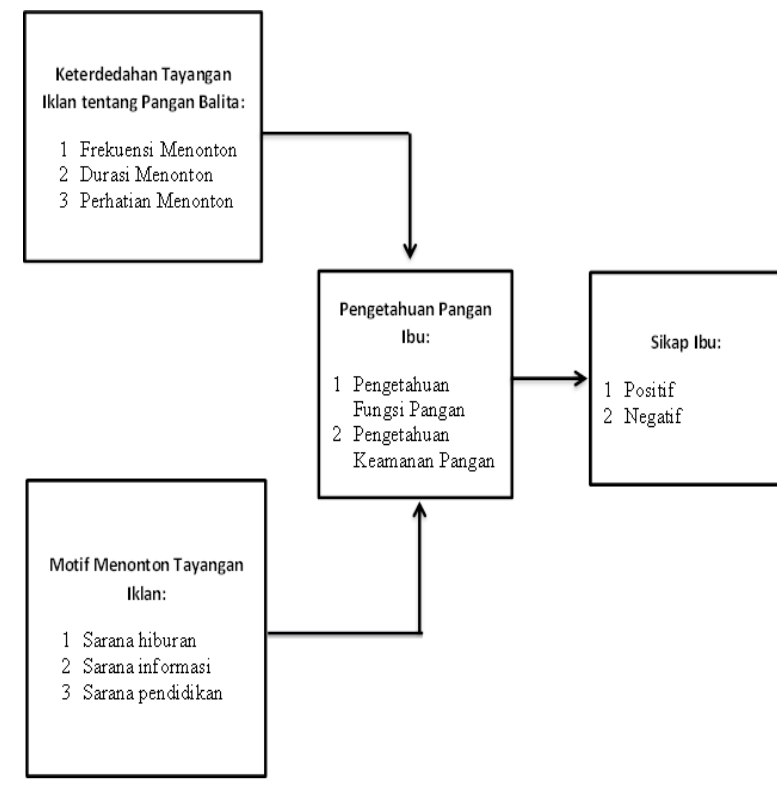

Gambar 1 Kerangka pemikiran hubungan keterdedahan tayangan iklan televisi dan pengetahuan dengan sikap ibu memberi pangan balita.

\section{Hipotesis Penelitian}

Berdasarkan kerangka pemikiran pada Gambar 1, maka dirumuskan hipotesis penelitian, yaitu: 1) Diduga terdapat hubungan positif antara tingkat keterdedahan tayangan iklan televisi yang terdiri dari frekuensi menonton, durasi menonton, tingkat perhatian menonton dan pengetahuan pangan ibu yang terdiri dari pengetahuan fungsi pangan, pengetahuan keamanan pangan, 2) Diduga terdapat hubungan positif antara tingkat keterdedahan tayangan televisi yang terdiri dari motif menonton dan pengetahuan pangan ibu yang terdiri dari pengetahuan fungsi pangan, pengetahuan keamanan pangan, 3) Diduga terdapat hubungan positif antara pengetahuan pangan ibu yang terdiri dari pengetahuan fungsi pangan, pengetahuan keamanan pangan dan sikap ibu yang terdiri dari positif, negatif.

\section{PENDEKATAN LAPANG}

Penelitian ini dilaksanakan di Desa Padasuka, Kecamatan Ciomas, Kabupaten Bogor. Pemilihan lokasi dilakukan secara purposive dengan mempertimbangkan bahwa lokasi penelitian termasuk daerah yang memiliki peswat televisi dan sinyal televisi sudah dapat diterima dengan baik. Penelitian ini dilaksanakan kurang lebih empat minggu, yang prosesnya terhitung pada bulan April 2017.

Penelitian ini menggunakan pendekatan data kuantitatif yang didukung oleh data kualitatif. Pendekatan data kuantitatif diperoleh dengan melakukan survei kepada responden yang menggunakan instrumen kuesioner di lapangan. Sedangkan data kualitatif diperoleh dengan cara wawancara mendalam terhadap informan, observasi lapang dan studi dokumentasi. Responden dalam penelitian ini adalah ibu yang memiliki anak balita (0-5 tahun) sebanyak 40 responden. Pemilihan responden dilakukan melalui metode Stratified random sampling. Teknik pengambilan sampel dalam penelitian ini yaitu stratified random sampling. Stratified random sampling ini digunakan untuk mengklarifikasikan dari ukuran bayi misalkan dikategorikan umur sekian sampai sekian, berat sekian sampai sekian agar kelihatan mana yang cenderung cocok untuk ibu sebagai populasi. Selain itu, pemilihan informan dilakukan secara purposive sesuai dengan rekomendasi dari warga dan jumlahnya tidak ditentukan. Penentuan informan ini dilakukan dengan menggunakan teknik bola salju (snowball).

Pengolahan data yang diperoleh secara kuantitatif melalui kuesioner diolah dengan menggunakan 
program Microsoft Excel 2010 dan SPSS version 24. Analisis data dilakukan dengan menggunakan uji korelasi Rank Sperman dengan nilai signifikansi $\alpha<0,05$. Selain itu, teknik pengolahan data kualitatif dianalisis melalui tiga tahap yaitu reduksi data, penyajian data, dan verifikasi data.

\section{HASIL DAN PEMBAHASAN}

\section{Profil dan Karakter Sosial-Ekonomi Desa Padasuka}

Desa Padasuka merupakan salah satu wilayah di Kecamatan Ciomas, Kabupaten Bogor, Jawa Barat. Desa Padasuka diresmikan atas dasar hukum peraturan daerah nomor 27 Tahun 2004 dengan koordianat $106.75861 \mathrm{BT} /-6.59542$ LS. Luas Desa Padasuka secara keseluruhan mencakup 132,80 Ha.

Kondisi penduduk di Desa Padasuka memiliki jumah penduduk sebesar 16793 jiwa yang terdiri dari 4747 KK. Jumlah penduduk laki-laki sebanyak 8434 jiwa, dan penduduk perempuan sebanyak 8359 jiwa dengan mayoritas pada usia kelompok umur 18-56 tahun. Terdiri dari 14 RW dengan 64 RT. Pekerjaan penduduk Desa Padasuka dominan sebagai buruh pabrik, selebihnya bermatapencaharian pedagang, pegawai swasta, tukang ojeg, petani, dan lainlain. Penduduk Desa Padasuka sebagian besar memiliki pendidikan yang tergolong rendah, dimana penduduk hanya berpendidikan hingga lulus SD. Pekerjaan penduduk Desa Padasuka dominan sebagai pegawai swasta, pegawai negeri sipil, TNI/Polri dan wiraswasta/pedagang.

\section{Keterdedahan Ibu Menonton Tayangan Iklan Desa Padasuka}

Komunikasi dan informasi khususnya dalam ketersediaan televisi sudah sangat memadai. Penduduk Desa Padasuka rata-rata sudah memiliki televisi. Stasiun-stasiun televisi juga sudah dapat tertangkap dengan jernih di desa ini. Penggunaan alat komunikasi seperti telepon genggam, internet juga sudah sangat memadai. Fasilitas sarana komunikasi dan informasi di Desa Padasuka sudah dapat terjangkau dengan baik. Dari keterdedahan ibu menonton tayangan iklan di televisi membuat ibu bertambah pengetahuannya. Apalagi dengan munculnya banyak iklan yang berhubungan dengan pangan balita. Pangan balita menjadi hal yang paling penting untuk diperhatikan karena terkait dengan kesehatan dan tumbuh kembang serta kecerdasan otak anak.

\begin{tabular}{|c|c|c|c|}
\hline Chanel TV & $\begin{array}{c}\text { Jenis } \\
\text { Produk } \\
\text { Pangan }\end{array}$ & Durasi & Isi Pesan \\
\hline $\begin{array}{l}\text { RCTI, } \\
\text { TRANS TV, } \\
\text { MNC TV, } \\
\text { INDOSIAR, } \\
\text { SCTV }\end{array}$ & SGM & $\begin{array}{l}60 \\
\text { detik }\end{array}$ & $\begin{array}{l}\text { Susu Generasi } \\
\text { Maju, susu } \\
\text { membuat badan } \\
\text { anak sehat dan } \\
\text { kuat }\end{array}$ \\
\hline $\begin{array}{l}\text { SCTV, } \\
\text { INDOSIAR, } \\
\text { MNC TV, } \\
\text { TRANS TV, } \\
\text { TRANS } 7\end{array}$ & Dancow & $\begin{array}{l}32 \\
\text { detik }\end{array}$ & $\begin{array}{l}\text { Di dalam } \\
\text { kandungan nya } \\
\text { terdapat minyak } \\
\text { ikan }\end{array}$ \\
\hline $\begin{array}{l}\text { TRANS TV, } \\
\text { TRANS 7, } \\
\text { RCTI, SCTV, } \\
\text { INDOSIAR, } \\
\text { MNC TV }\end{array}$ & Bebelac & $\begin{array}{l}30 \\
\text { detik }\end{array}$ & $\begin{array}{l}\text { Anak menjadi } \\
\text { cepat tanggap } \\
\text { dan memiliki } \\
\text { rasa peduli }\end{array}$ \\
\hline $\begin{array}{l}\text { ANTV, } \\
\text { SCTV, } \\
\text { TRANS TV, } \\
\text { TRANS } 7\end{array}$ & Milna & $\begin{array}{l}30 \\
\text { detik }\end{array}$ & $\begin{array}{l}\text { Bentuk khusus, } \\
\text { gampang larut, } \\
\text { ahli makanan } \\
\text { bayi }\end{array}$ \\
\hline $\begin{array}{l}\text { RCTI, SCTV, } \\
\text { TRANS TV, } \\
\text { TRANS TV }\end{array}$ & Promina & $\begin{array}{l}15 \\
\text { detik }\end{array}$ & $\begin{array}{l}\text { Terdapat omega } \\
3 \text {, serat dan zat } \\
\text { besi }\end{array}$ \\
\hline
\end{tabular}

Gambar 2 Jenis Iklan yang sering ditonton oleh responden di Desa Padasuka, 2017

Data mengenai ibu berdasarkan status keterdedahan tayangan iklan dapat dilihat dalam Tabel 1.

Tabel 1 Jumlah dan persentase responden menurut tingkat keterdedahan

\begin{tabular}{ccc}
\hline $\begin{array}{c}\text { Tingkat } \\
\text { keterdedahan }\end{array}$ & Jumlah (n) & $\begin{array}{c}\text { Persentase } \\
(\%)\end{array}$ \\
\hline Rendah & 8 & 20.0 \\
Tinggi & $\mathbf{3 2}$ & $\mathbf{8 0 . 0}$ \\
\hline Total & 40 & 100.0 \\
\hline
\end{tabular}

Berdasarkan Tabel 1 menunjukkan bahwa keterdedahan ibu terhadap tayangan iklan tentang pangan balita di televisi tergolong kategori terdedah tinggi yaitu sebesar $80.0 \%$. Kategori tinggi dapat diuraikan yaitu, menonton 6-10 tayangan bahkan $>10$ tayangan dalam sehari, menonton tayangan iklan sampai habis bahkan menonton tayangan dari awal hingga pertengahan 
dari tayangan iklan dan dari pertengahan sampai habis tayangan iklan, memperhatikan tayangan, tidak melakukan kegiatan lain dan memperhatikan dan melakukan kegiatan lain. Hal ini dikarenakan ibu suka menonton televisi namun tidak selalu melihat tayangan iklan tentang pangan balita di televisi. Selain itu, responden sebagian besar bekerja sebagai ibu rumah tangga, alokasi waktu bekerja mereka lebih banyak untuk mengurusi semua pekerjaan rumah tangga.

Sejumlah elemen masyarakat yang bergerak di bidang kesehatan ibu dan anak mendukung pemerintah tetap mencantumkan klausul pelarangan iklan susu formula bagi anak usia 0-3 tahun pada Rancangan Peraturan Pemerintah tentang Label dan Iklan Pangan. Hal itu bertujuan untuk mencegah promosi silang susu formula yang menghambat program pemberian air susu ibu eksklusif. (Wijaya 2017) mengatakan dalam rancangan peraturan pemerintah (RPP) label dan iklan pangan yang sedang dibahas, iklan susu formula yang dilarang ialah iklan susu formula bagi anak usia 0-3 tahun, terdiri dari susu formula bayi (0-6 bulan), susu formula lanjutan (7-12 bulan), dan susu formula pertumbuhan (2-3 tahun).

RPP tersebut merevisi PP Nomor 69 Tahun 1999 tentang Label dan Iklan Pangan yang hanya mencantumkan pelarangan susu formula bagi anak berusia di bawah 1 tahun, susu formula bayi (0-6 bulan), dan susu formula lanjutan (7-12 bulan). Jika pelarangan hanya pada susu formula bagi anak berusia 0-2 tahun atau tetap seperti pada PP No 69/1999, yakni melarang iklan susu formula bagi anak usia di bawah 1 tahun, dikhawatirkan terjadi promosi silang dari industri susu formula. Saat industri susu formula gencar mempromosikan susu formula pertumbuhan (untuk usia 3 tahun), orangtua cenderung mencari susu formula untuk anaknya yang berusia di bawah itu.

Berdasarkan hipotesa dari keterdedahan tayangan iklan maka semakin terdedah, semakin negatif sikap ibu dalam memberikan pangan balita contoh ASI. Semakin negatif disini menjelaskan bahwa ibu akan semakin tertarik dan menggunakan susu formula. Namun, berdasarkan data yang diperoleh, semakin terdedah ibu oleh iklan, semakin positif sikap ibu dalam memberikan ASI. Hal tersebut, dapat menjustifikasi kebijakan pemerintah karena terlihat dari jumlah 40 responden yang memiliki sikap memilih memberikan ASI kepada anaknya ada 35 orang, untuk 5 orang responden memilih susu formula. Alasan pemerintah mengeluarkan kebijakan menurut peneliti belum bisa direalisasikan. Karena dari alasan ibu tidak memberikan ASI, ibu tidak dapat mengeluarkan ASI Ekslusif untuk anaknya. Hal ini menyatakan bahwa ibu sudah mengetahui manfaat yang dimiliki oleh ASI, sehingga keterdedahan ibu tidak menurunkan sikap ibu untuk memberikan ASI kepada anaknya. Mengetahui manfaat yang dimiliki oleh ASI berdasarkan informasi yang mereka peroleh melalui televisi dan kegiatan posyandu yang dilakukan bidan dan kader.

\section{Motif Ibu Menonton Tayangan Iklan Televisi tentang Pangan Balita}

Motif menonton merupakan dorongan responden untuk menonton tayangan iklan ditelevisi. Motif ini diukur berdasarkan motivasi dorongan responden dalam menonton tayangan iklan ditelevisi. Kategori motif dibagi menjadi tiga kategori yaitu kategori motif dapat dikatakan tinggi apabila ibu paling banyak yang menjawab ya dengan memilih motif tersebut. Kategori motif dapat dikatakan sedang apabila ibu banyak yang menjawab ya dengan memilih motif tersebut sejumlah kurang lebih hampir mendekati dengan banyaknya motif yang dituju pertama. Kategori motif dapat dikatakan rendah apabila ibu paling sedikit menjawab ya dalam pernyataan yang dilampirkan di kuesioner. Data mengenai ibu berdasarkan motif menonton dapat dilihat dalam Tabel 2 .

Tabel 2 Jumlah dan persentase responden menurut motif menonton

\begin{tabular}{llcc}
\hline \multirow{2}{*}{ Pernyataan } & \multicolumn{2}{c}{ Ya } \\
\cline { 2 - 4 } & & $\mathrm{n}$ & $\%$ \\
\hline 1. & Sarana hiburan ibu & 29 & 72.5 \\
\hline 2. & Sarana informasi ibu & 9 & 22.5 \\
\hline 3. & $\begin{array}{l}\text { Sarana pendidikan ibu } \\
\text { (pengetahuan) }\end{array}$ & 17 & 42.5 \\
\hline
\end{tabular}

Berdasarkan Tabel 2 menunjukkan bahwa motif ibu menonton terhadap tayangan iklan pangan 
balita di televisi berada dalam kategori motif pertama yaitu sebesar $72.5 \%$. Arti dari kata motif pertama adalah dominan dimana pilihan yang paling banyak ibu pilih sebagai motif. Dilihat dari responden merupakan ibu rumah tangga, perempuan pada umumnya sangat suka menonton sinetron, sehingga mereka condong melihat bahwa motif menonton iklan tentang pangan balita adalah sebagai hiburan.

Motif ibu yang kedua sebagai sarana pendidikan yaitu sebesar $42.5 \%$, motif ibu sebagai sarana pendidikan dapat diartikan untuk ibu menambah pengetahuan, ibu mendapatkan pengetahuan yang baru tidak hanya lewat kegiatan posyandu dan sosial media melainkan dari iklan di televisi pun dapat menambah pengetahuan. Melalui televisi ibu memilih pangan untuk anak sehat dan cerdas, mengetahui jenis-jenis pangan terbaru balita dan mengetahui jenis pangan sesuai dengan umurnya. Maka dari itu, motif yang ketiga adalah motif yang paling sedikit yaitu sebesar $22.5 \%$. Motif ibu paling sedikit sebagai sarana informasi dimana ibu memberitahu anak tentang pangan yang sehat untuk dikonsumsi.

\section{Pengetahuan Ibu tentang Pangan Balita}

Peranan orangtua sangat dibutuhkan untuk membentuk perilaku makan yang sehat. Pengetahuan adalah hasil "tahu" yang terjadi setelah penginderaan terhadap suatu objek tertentu. Penerimaan perilaku atau adopsi perilaku yang didasar pengetahuan, kesadaran dan sikap yang positif akan bersikap langgeng (Notoatmodjo, 1997). Seorang ibu dalam hal ini harus mengetahui, mau, dan mampu menerapkan makan yang seimbang atau sehat dalam keluarga karena anak akan meniru perilaku makan dari orangtua dan orang-orang di sekelilingnya dalam keluarga.

Kebutuhan gizi pada anak dapat tercukupi dengan baik apabila pengetahuan ibu tentang gizi juga baik, salah satunya pengetahuan dalam memberi pangan yang tepat bagi balita yaitu makanan yang sesuai dengan kebutuhan tubuh mereka. Selain itu, pengetahuan ibu yang baik juga dapat memberikan asupan makanan dan vitamin yang seimbang sehingga anak tidak mudah terkena penyakit. Pengetahuan ibu dapat diukur melalui beberapa pernyataan yang berupa pengetahuan fungsi pangan dan pengetahuan keamanan pangan.

Pengetahuan fungsi pangan ibu yang diukur berdasarkan pengertian makanan bergizi, pengetahuan mengenai jenis mineral, vitamin, zat besi dan kalsium untuk pertumbuhan dan perkembangan anak dan pengetahuan mengenai isi pesan yang terdapat di iklan televisi. Pengetahuan kemanan pangan merupakan salah satu faktor penting disamping mutu fisik, gizi dan cita rasa.

Pengetahuan keamanan pangan ibu yang diukur berdasarkan pengertian tentang kondisi dan upaya yang diperlukan untuk mencegah pangan dari kemungkinan cemaran biologis, kimia, dan benda lain yang dapat mengganggu, merugikan, dan membahayakan kesehatan manusia. Aspek keamanan apabila tidak diperhatikan, maka makanan dapat berbalik menjadi sumber penyakit dan kematian.

Kategori pengetahuan pangan ibu dibagi menjadi tiga kategori yaitu kategori tinggi dengan skor 3140 dan kategori rendah dengan skor 20-30. Data mengenai ibu berdasarkan pengetahuan pangan dapat dilihat dalam Tabel 3.

Tabel 3 Jumlah dan persentase responden menurut tingkat pengetahuan pangan ibu

\begin{tabular}{ccc}
\hline $\begin{array}{c}\text { Tingkat } \\
\text { Pengetahuan } \\
\text { Pangan Ibu }\end{array}$ & Jumlah (n) & $\begin{array}{c}\text { Persentase } \\
(\%)\end{array}$ \\
\hline Rendah & 5 & 12.5 \\
Tinggi & $\mathbf{3 5}$ & $\mathbf{8 7 . 5}$ \\
\hline Total & 40 & 100.0 \\
\hline
\end{tabular}

Berdasarkan Tabel 3 menunjukkan bahwa pengetahuan tentang pangan ibu berada pada kategori tinggi yaitu sebesar $87.5 \%$. Pendidikan yang dimiliki oleh ibu memang sudah tinggi terhadap pengetahuan pangan balita, namun tidak terlalu berhubungan dengan tayangan iklan. Sebenarnya pengetahuan tersebut sudah mereka dapatkan dari posyandu dan juga pendidikan ibu yang semakin tinggi yaitu berada pada tingkat Sekolah Menengah Atas (SMA) dan perkuliahan, karena lewat pendidikan ibu diajarkan mengenai makan-makanan bergizi terhadap anak. Beda halnya dengan ibu yang berpendidikan hanya 
sampai Sekolah Dasar tetapi tidak pandai menggunakan tekhnologi seperti handphone atau komputer. Selain pendidikan, pengetahuan pangan ibu dapat dilihat dari ibu yang sudah canggih menggunakan tekhnologi, seperti handphone. Dari handphone ibu dapat meningkatkan pengetahuan tentang pangan balita yang bermanfaat lewat internet.

Selain itu, pengetahuan pangan yang berada pada kategori tinggi dapat dilihat dari umur ibu, dimana ibu yang berumur 25-35 tahun rata-rata sudah mengetahui bagaimana cara pemberian makanan bergizi kepada pihak anak, berbeda dengan ibu yang baru menikah pada usia muda dan memiliki anak rata-rata kurang mengerti dalam pemberian makanan bergizi kepada anak. Faktor pengalaman menentukan juga terhadap pengetahuan fungsi pangan ibu. Adapun pengalaman tersebut dapat dilihat dari banyaknya anak yang dimiliki oleh seorang ibu dan lingkungan sosialnya.

\section{Sikap Ibu Memberi Pangan Balita}

Sikap ibu yang diukur berdasarkan adanya kesadaran ibu dalam memberi pangan pada balita dalam tayangan iklan tentang pangan balita di televisi. Sikap ibu mengenai memberi pangan pada anak merupakan faktor yang menentukan seseorang untuk berperilaku memberikan makanan yang tepat untuk anak. Makanan yang tepat buat anak diberikan agar anak dapat memenuhi kebutuhan gizinya. Sikap ibu yang yang di dapat dari interaksi sosial seperti lingkungan, dapat dengan mudah mempengaruhi perilaku ibu dalam memberikan makanan di rumah. Menurut penelitian yang dilakukan oleh Hafrida, kebiasaan makan yang diajarkan ibu kepada anak akan mempengaruhi pola makan anak sehingga anak dapat memutuskan makanan yang dikonsumsinya. Kategori sikap ibu dibagi menjadi tiga yaitu, negatif : $0-3$, dan positif : 4-5. Data mengenai ibu berdasarkan sikap ibu dapat dilihat dalam Tabel 4.

Tabel 4 Jumlah dan persentase responden menurut sikap Ibu

\begin{tabular}{lcc}
\hline Sikap Ibu & Jumlah (n) & Persentase (\%) \\
\hline Negatif & 5 & 12.5 \\
Positif & 35 & 87.5 \\
\hline Total & 40 & 100.0 \\
\hline
\end{tabular}

Berdasarkan Tabel 13 menunjukkan bahwa sikap ibu berada pada kategori tinggi yaitu sikap ibu positif sebesar $87.5 \%$. Hal ini menunjukkan bahwa sikap positifnya nya seorang ibu, dengan memberikan ASI, ibu dapat menghemat biaya pengeluaran keluarga. Ada $12.5 \%$ ibu yang negatif dalam memilih sikap yang telah ditentukan oleh peneliti yaitu, menjawab pernyataan tidak setuju 2 kali dan menjawab pernyataan setuju 3 kali. Hal ini menunjukkan sikap negatif bukan sepenuhnya ibu memiliki sikap negatif melainkan sikap ibu kurang positif dalam memberi pangan pada balita, dikarenakan ada beberapa ibu menjadi seorang wanita karir dimana dirinya mempunyai rasa sadar dan waspada pada tingkat pengetahuan yang lebih banyak dari internet bahkan dari tempat pekerjaan nya dibandingkan dari tayangan iklan di televisi.

Selain itu, ibu merasa lebih mudah memberikan susu formula dibandingkan memberikan ASI eksklusif alasan ibu adalah tidak adanya waktu untuk memberikan ASI secara langsung, terkadang waktu kerja yang tidak sesuai dengan pemberian ASI eksklusi karena jarak tempat kerja ibu yang jauh dari tempat tinggal. Lalu, ibu lebih sering membelikan makanan diluar untuk anaknya dibandingkan memasak sendiri karena menurutnya akan lebih praktis dibandingkan ibu harus memasak ketika ibu pulang dari kantor dalam keadaan lelah. Beda hal nya dengan seorang ibu yang hanya menjadi ibu rumah tangga saja. Karena disaat ibu tidak sedang mengurus anak, waktu luang ibu digunakan untuk menonton televisi dan melihat tayangan iklan tentang pangan balita yang menumbuhkan rasa sadar dan waspada terhadap pilihan pangan anaknya. Ibu yang tidak memiliki perkejaan lain diluar ativitas di rumah, selalu menjawab pernyataan yang diberikan peneliti yaitu ibu suka memasak sendiri disbanding membelikan makanan diluar untuk anaknya, selain menghemat biaya penguluaran keluarga ibu tidak khawatir atas pilihan makanan yang disajikan untuk anak karena menurut ibu makanan yang masak sendiri dengan beli diluar itu jauh lebih sehat dan steril. 


\section{Analisis Hubungan Keterdedahan Tayangan Iklan Televisi dengan Pengetahuan Pangan Ibu}

Hasil uji Rank Spearman tingkat keterdedahan tayangan iklan dan tingkat pengetahuan ibu memiliki koefisien korelasi sebesar 0.378 dengan nilai probabilitas hubungan nyata $(\mathrm{p}<0.05)$, artinya adanya hubungan yang signifikan karena nilai signifikansi sehingga $\mathrm{H}_{1}$ diterima. bahwa semakin tinggi keterdedahan ibu menonton tayangan iklan di televisi maka semakin tinggi tingkat pengetahuan pangan ibu tentang pangan. Hubungan tingkat keterdedahan menonton tayangan iklan dengan tingkat pengetahuan pangan ibu dapat dilihat dalam Tabel 5.

Tabel 5 Hubungan tingkat keterdahan ibu dengan tingkat pengetahuan pangan ibu

\begin{tabular}{|c|c|c|c|c|c|c|}
\hline \multirow{3}{*}{$\begin{array}{c}\text { Tingkat } \\
\text { keterdedaha } \\
\text { n ibu }\end{array}$} & \multicolumn{4}{|c|}{$\begin{array}{c}\text { Tingkat } \\
\text { pengetahuan } \\
\text { pangan ibu }\end{array}$} & \multirow{2}{*}{\multicolumn{2}{|c|}{ Total }} \\
\hline & \multicolumn{2}{|c|}{ Rendah } & \multicolumn{2}{|c|}{ Tinggi } & & \\
\hline & $\mathrm{n}$ & $\%$ & $\mathrm{n}$ & $\%$ & $\mathrm{n}$ & $\%$ \\
\hline \multirow{2}{*}{ Rendah } & & 37. & & 62. & & 100. \\
\hline & 3 & 5 & 5 & 5 & 8 & 0 \\
\hline \multirow{2}{*}{ Tinggi } & & & 3 & 93. & 3 & 100. \\
\hline & 2 & 6.3 & 0 & 8 & 2 & 0 \\
\hline \multirow{2}{*}{ Total } & & 12. & 3 & 87. & 4 & 100. \\
\hline & 5 & 5 & 5 & 5 & 0 & 0 \\
\hline
\end{tabular}

Berdasarkan Tabel 5 menunjukkan bahwa 93.8\% memiliki tingkat keterdedahan ibu yang tinggi dan tingkat pengetahuan pangan ibu yang tinggi. Hal ini dipengaruhi oleh faktor lingkungan sekitar Desa Padasuka yang mayoritas menjadi ibu rumah tangga sibuk dengan mengurus anak dan pekerjaan rumah tangga yang membuat ibu menjadi menggunakan waktu luangnya untuk menonton televisi, mayoritas ibu sudah memiliki handphone dan pandai menggunakannya untuk menambah pengetahuan ibu, terkait memberi pangan apa saja yang sehat untuk anak-anaknya, maka dari itu ibu mendapatkan informasi terkait pangan balita tidak hanya dari iklan di televisi melainkan bisa di dapat dari internet yang dengan mudah di akses dimana pun dan kapan pun. Hal tersebut didukung oleh pernyataan Furkonulhakin (1989) menyebutkan bahwa keterdedahan terhadap media sangat berkaitan dengan perilaku seseorang dalam mengumpulkan informasi dari berbagai sumber dan media di lingkungannya.

\section{Analisis Hubungan Motif Menonton Tayangan Iklan Televisi dengan Pengetahuan Pangan Ibu}

Hasil uji Rank Spearman 0.316 menyebutkan bahwa nilai korelasi kuat. Hasil olah data SPSS ini menunjukkan adanya hubungan yang signifikan karena nilai signifikansi sehingga $\mathrm{H}_{1}$ diterima, artinya terdapat hubungan antara variabel motif sebagai hiburan dengan tingkat pengetahuan pangan ibu. Namun, untuk sebagai sarana informasi dan sarana pendidikan menyebutkan bahwa nilai tidak berkorelasi. Hubungan motif menonton tayangan iklan dan tingkat pengetahuan ibu dapat dilihat dalam Tabel 6.

Tabel 6 Hubungan motif menonton tayangan iklan dengan tingkat pengetahuan ibu

\begin{tabular}{cccccccc}
\hline Motif & \multicolumn{4}{c}{ Tingkat pengetahuan ibu } \\
\cline { 2 - 8 } $\begin{array}{c}\text { menonton } \\
\text { tayangan } \\
\text { iklan }\end{array}$ & $\mathrm{n}$ & $\%$ & $\mathrm{n}$ & $\mathrm{n}$ & $\%$ & $\mathrm{n}$ & $\%$ \\
\hline $\begin{array}{l}\text { Sarandah hiburan ibu } \\
\text { Ya }\end{array}$ & 0 & 0.0 & 3 & 10.3 & 26 & 89.7 \\
\hline
\end{tabular}

Sarana informasi ibu

Ibu memberitahu anak tentang pangan yang sehat untuk dikonsumsi

\begin{tabular}{lllllll} 
Ya & 1 & 11.1 & 1 & 11.1 & 7 & 77.8 \\
\hline
\end{tabular}

Sarana pendidikan ibu (pengetahuan)

Memilih untuk anak sehat dan cerdas sesuai iklan di televisi

$\begin{array}{lllllll}\text { Ya } & 0 & 0.0 & 1 & 25.0 & 3 & 75.0\end{array}$

Mengetahui jenis-jenis pangan terbaru balita di televisi

$\begin{array}{lllllll}\text { Ya } & 0 & 0.0 & 3 & 50.0 & 3 & 50.0\end{array}$

Mengetahui jenis pangan sesuai dengan umurnya

\begin{tabular}{lllllll}
$\mathrm{Ya}$ & 0 & 0.0 & 0 & 0.0 & 7 & 100.0 \\
\hline
\end{tabular}

Berdasarkan Tabel 6 menunjukkan bahwa motif dominan ibu menonton tayangan iklan di televisi adalah sebagai sarana hiburan. Motif ibu yang berkenaan dengan sarana pendidikan dengan cara menambah pengetahuan yang dikategorikan sebagai memilih untuk anak sehat dan cerdas sesuai iklan di televisi, mengetahui jenis-jenis pangan terbaru balita di televisi dan mengetahui jenis pangan sesuai dengan umurnya. Jadi, jika dilihat dari hasil lapang motif menonton ibu 
tidak ada hubungannya dengan pengetahuan pangan ibu.

\section{Analisis Hubungan Pengetahuan dengan Sikap Ibu Memberi Pangan Balita}

Hasil uji Rank Spearman tingkat pengetahuan pangan ibu dan sikap ibu memberi pangan balita memiliki koefisien korelasi sebesar 0.086 dengan nilai probabilitas hubungan nyata $(\mathrm{p}<0.05)$, artinya tidak adanya hubungan yang signifikan karena nilai signifikansi sehingga $\mathrm{H}_{1}$ ditolak, bahwa semakin tinggi tingkat pengetahuan ibu maka tidak semakin positif sikap ibu dalam memberi pangan. Hubungan tingkat keterdedahan menonton tayangan iklan dengan tingkat pengetahuan pangan ibu dapat dilihat dalam Tabel 7.

Tabel 7 Hubungan tingkat pengetahuan pangan ibu dengan sikap ibu memberi pangan balita

\begin{tabular}{ccccccc}
\hline \multirow{2}{*}{$\begin{array}{c}\text { Tingkat } \\
\text { pengetahuan } \\
\text { pangan ibu }\end{array}$} & \multicolumn{4}{c}{\begin{tabular}{c}
\multicolumn{3}{c}{ pikap ibu memberi } \\
pangan balita
\end{tabular}} & \multirow{2}{*}{ Total } \\
\cline { 2 - 5 } & Negatif & \multicolumn{2}{c}{ Positif } & & \\
\cline { 2 - 6 } & $\mathrm{n}$ & $\%$ & $\mathrm{n}$ & $\%$ & $\mathrm{n}$ & $\%$ \\
\hline Rendah & 1 & 20.0 & 4 & 80.0 & 5 & 100.0 \\
Tinggi & 4 & 11.4 & 31 & 88.6 & 35 & 100.0 \\
\hline Total & 5 & 12.5 & 35 & 87.5 & 40 & 100.0 \\
\hline
\end{tabular}

Berdasarkan Tabel 7 menunjukkan bahwa pengetahuan pangan ibu tinggi yaitu sebesar 88.6\% memiliki sikap ibu memberi pangan balita yang positif. Kecendrungan ini dapat dilihat dari pengetahuan lebih tinggi namun masih ada ibu yang memiliki sikap kurang positif. Hal ini dikarenakan adanya variabel antara dimana ibu yang menjadi responden dalam penelitian ini merupakan sebagian besar ibu rumah tangga namun ada juga ibu yang bekerja diluar rumah yaitu ibu yang memiliki status pekerjaan sebagai wanita karir. Ibu yang memiliki pengetahuan tinggi namun masih memiliki sikap yang kurang positif dibuktikan dengan hasil lapang yaitu ibu setuju dengan waspada terhadap pilihan pangan anak, ibu pun merasa yakin susu dapat membantu pertumbuhan tulang anak, dengan memberikan ASI lebih menghemat biaya, namun ibu tidak setuju dengan sikap yang menunjukkan jika ibu merasa lebih mudah memberikan ASI dibandingkan dengan memberikan susu formula dan ibu tidak setuju dengan mengutamakan masak daripada beli makanan anak diluar. Ibu tidak memiliki waktu dengan dirinya memberikan ASI terlebih dahulu sebelum berangkat bekerja dan ibu juga tidak ada kesempatan untuk terus menerus memasak untuk anaknya karena ibu bekerja dikantor tidak selalu bersama dengan anaknya disetiap harinya kecuali hari libur.

\section{SIMPULAN DAN SARAN}

\section{Simpulan}

Simpulan yang didapatkan dari penelitian ini adalah sebagai berikut:

1. Hasil uji Rank Spearman tingkat keterdedahan tayangan iklan dan tingkat pengetahuan ibu memiliki koefisien korelasi sebesar 0.378 dengan nilai probabilitas hubungan nyata $(\mathrm{p}<0.05)$, artinya adanya hubungan yang signifikan karena nilai signifikansi sehingga $\mathrm{H}_{1}$ diterima. bahwa semakin tinggi keterdedahan ibu menonton tayangan iklan di televisi maka semakin tinggi tingkat pengetahuan pangan ibu tentang pangan.

2. Hasil uji Rank Spearman 0.316 menyebutkan bahwa nilai korelasi kuat. Hasil olah data SPSS ini menunjukkan adanya hubungan yang signifikan karena nilai signifikansi sehingga $\mathrm{H}_{1}$ diterima, artinya terdapat hubungan antara variabel motif sebagai hiburan dengan tingkat pengetahuan pangan ibu. Namun, untuk sebagai sarana informasi dan sarana pendidikan menyebutkan bahwa nilai tidak berkorelasi.

3. Hasil uji Rank Spearman tingkat pengetahuan pangan ibu dan sikap ibu memberi pangan balita memiliki koefisien korelasi sebesar 0.086 dengan nilai probabilitas hubungan nyata $(p<0.05)$, artinya tidak adanya hubungan yang signifikan karena nilai signifikansi sehingga $\mathrm{H}_{1}$ ditolak, bahwa semakin tinggi tingkat pengetahuan ibu maka tidak semakin positif sikap ibu dalam memberi pangan. Hal ini karena dipengaruhi oleh pengetahuan dengan sikap yang belum selaras sama tujuan ibu dalam memberi 
pangan pada balita. Ada ibu yang pengetahuan pangan nya tinggi namun, ibu masih suka membelikan makanan untuk anaknya diluar tidak memasak sendiri, padahal ibu tau resiko apa saja yang akan berdampak negatif untuk anaknya.

\section{Saran}

Saran yang diajukan penulis berdasarkan hasil penelitian ini, yaitu:

1. Walaupun ibu berstatus bekerja wanita karir, ibu perlu selektif dalam memberi pangan untuk anaknya.

2. Ibu perlu mempertimbangkan jika sebenarnya ASI Ekslusif jauh lebih baik dan itu wajib diberikan walaupun status bekerja ibu sebagai wanita karir. Untuk para ibu yang bekerja di luar rumah dapat terlebih dahulu memeras ASI dan menyimpannya di lemari es, sehingga pada saat ibu sedang pergi bekerja tidak perlu lagi khawatir, karena anak mereka tetap terjamin mendapatkan ASI Ekslusif.

3. Ibu perlu ikut serta secara langsung terhadap kegiatan posyandu anak yang diadakan setiap satu bulan sekali agar anak tetap terpantau kesehatannya dan ibu bisa berkonsultasi dengan bidan secara santai tanpa harus membayar mahal.

4. Memfilter informasi dari iklan di televisi bukan berarti harus dengan tidak menyaksikan iklan tersebut, tidak menggunakan iklan tersebut atau langsung beranggapan bahwa iklan tersebut bohong. Namun, lebih kepada memfilter informasi dengan tidak menerima informasi dari iklan tanpa melalui pemikiran yang diiringi pengetahuan dan norma yang berkaitan dengan isi pesan iklan tersebut.

\section{DAFTAR PUSTAKA}

Andika, Jurian. 2008. Hubungan keterdedahan terhadap media massa dengan pengetahuan tentang kebijakan pemerintah mengenai flu burung (Kasus pada mahasiswa Fakultas Peternakan IPB). [skripsi]. Bogor (ID): Institut Pertanian Bogor.

Ardianto E. 2001. Keterdedahan tayangan iklan televisi terhadap kecenderungan perilaku konsumerime masyarakat desa di Kecamatan Rancaekek Kabupaten Bandung Barat. [tesis]. Bogor (ID): Institut Pertanian Bogor.

Azwar S. 2003. Sikap Manusia: Teori dan Pengukurannya. Jakarta (ID): Pustaka Pelajar

Hartono A. 2006. Terapi Gizi dan Diet Rumah Sakit. Jakarta: EGC.

Kementrian Kesehatan RI. Profil Kesehatan Indonesia Tahun 2012. Jakarta 2013.

http://jukeunila.com/wp-content/uploads/2016/03/5Julita-Nainggolan.pdf

Notoatmodjo, S. 2003. Pendidikan dan Perilaku Kesehatan. Jakarta: Rineka Cipta

Notoatmodjo, S (2007). Promosi Kesehatan dan Ilmu Perilaku. Jakarta: Rineka Cipta

Rodman, G. 2006. Mass Media In Changing World. First Edition. Mc Graw and Hill Inc. USA.

Sarwono SW. 2002. Psikologi Sosial: Individu dan teori-teori Psikologi Sosial. Jakarta (ID): Balai Pustaka

Schiffman, Leon. G and Kanuk, Leslie Lazar. 1994. Consumer Behavior. Prentice

Soetjiningsih. 2002. Tumbuh kembang anak. Jakarta. EGC

Suhardjo. 1989. Perencanaan Pangan dan Gizi. Departemen Pendidikan dan Kebudayaan Direktorat Jenderal Pendidikan Tinggi Pusat Antar Universitas Pangan dan Gizi. IPB.

Sutisna RJ. 2000. Hubungan keterdedahan tayangan iklan di media televisi dengan perilaku konsumsi masyarakat Desa Kabupaten Bojonegoro Jawa Timur. [tesis]. Bogor (ID). Institut Pertanian Bogor.

Taryoto, AH. 1991. Konsumsi Bahan Pangan Suatu Tinjauan Sikap dan Perilaku Individu. Majalah Pangan Vol II.

Wijaya. 1996. Ners Jurnal Keperawatan Volume 10. No 1, Oktober $2014: 159-166$

WHO. 2011. Global Status Report on Noncommunicable Diseases 2010. http://www.who.int/nmh/publications/ncd repor t_chapter1.pdf Hall, Inc, Englewood Cliffs, New Jersey. 